\title{
Szöllôsi Barnabás
}

\section{A Hideg napok genezise - Ötlettól a filmig}

\begin{abstract}
Absztrakt
A Magvetô Könyvkiadó Ötlettól a filmig címú könyvsorozatának elsô darabja 1967-ben jelent meg Cseres Tibor és Kovács András Hideg napokjáról. A kötet szerkesztésén folyamatosan tetten érhetó a Kádár-korszak kultúrpolitikájára jellemzô népnevelô, népmúvelô szándék. Ennek szellemében a kötet a film referenciális történelmi olvasatát hangsúlyozza dokumentumgyújtemények, filmankétok és szerzôi kommentárok segítségével, noha Kovács alkotása modernista elbeszéléstechnikája miatt is tett szert kultikus státuszára a magyar filmtörténetben. A tanulmány a filmet bemutató kötet kultuszkritikai vizsgálatát, s ennek kapcsán a film újraolvasását nyújtja.

\section{Szerzô}

Szöllôsi Barnabás 1991-ben született Budapesten, 2016-ban szerzett mesterfokozatú diplomát a Színház- és Filmmúvészeti Egyetem filmdramaturg-forgatókönyvíró szakán. Jelenleg szintén az SZFE-n végzi PhD-kutatását, amelyben a forgatókönyv irodalmi autonómiájával, a magyar forgatókönyvírás történetével, baloldali filmelmélettel és a kreatív írás pedagógiai hasznosíthatóságával foglalkozik.
\end{abstract}

https://doi.org/10.31176/apertura.2019.15.2.6 


\section{Szöllôsi Barnabás}

\section{A Hideg napok genezise - Ötlettól a filmig}

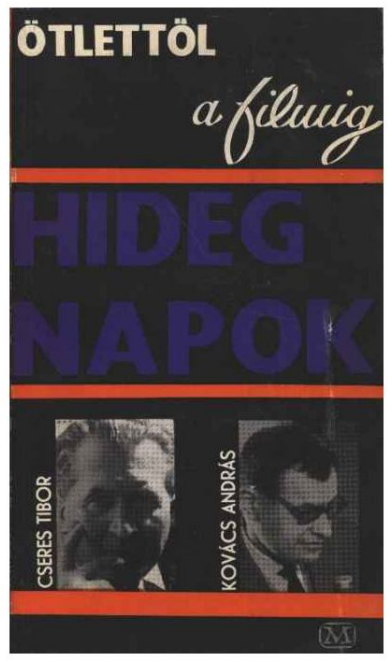

A kötet borítója

\section{Elôzetes megjegyzés}

Az alábbi tanulmány egy tágabb, a Színház- és Filmmúvészeti Egyetemen végzett PhD-kutatás részeredménye. Doktori munkám a forgatókönyvírás irodalmi aspektusaival foglalkozik, s ennek keretén belül vizsgálom a magyar nyelven publikált forgatókönyveket is, így a Magvetô Ötlettól a filmig címú könyvsorozatát is feldolgozom.

A sorozat kötetei kronológiai sorrendben: Kovács András, Cseres Tibor: Hideg napok, 1967; Jancsó Miklós, Hernádi Gyula: Szegénylegények, 1968; Kovács András: Falak, 1968; Máriássy Judit, Máriássy Félix: Imposztorok, 1970; Grundvalszky Ferenc, Hernádi Gyula: Vörös rekviem, 1977; Fábri Zoltán: Magyarok, 1978; Galgóczi Erzsébet, Mihályfi Imre: A közös bün, 1978; Bacsó Péter: Áramütés, 1979; Kovács András, Gáll István: A ménesgazda, 1979; Sára Sándor, Csóori Sándor: Nyolcvan huszár, 1980; Sándor Pál, Mándy Iván, Tóth Zsuzsa: Szabadits meg a gonosztól, 1980; Kovács András: Októberi vasárnap, 1980. 
Kutatásom során nemcsak a hazai forgatókönyv-publikálás gyakorlatát vizsgálom a sorozat kapcsán, hanem a következô kérdésekre is próbálok választ találni: Mi volt a sorozat célja? Ki lehetett a könyvek célközönsége? Mennyiben tekinthetjük a sorozatban bemutatott filmeket kanonikusnak? Mennyiben és miért tér el a sorozat kánonja a mai kánontól?

\section{Bevezetés}

Cseres Tibor regénye az 1942-es „újvidéki razzia”, avagy „újvidéki vérengzésként” elhíresült háborús eseményekről 1964-ben jelent meg a Magvetônél. Kovács András a könyv alapján készült filmjét 1966-ban mutatták be. Érdekes, hogy Kovács ezt a két évet sokallta: „Nem akarom elismételni, hogy került a kezembe véletlenül és elég késôn Cseres regénye" - írja a film készítésének és befogadásának körülményeirôl szóló esszéjében. ${ }^{[1]}$ A film 1966-ban fôdíjat nyert a Karlovy Vary Nemzetközi Filmfesztiválon, 1967-ben pedig a Magyar Filmszemle födíját kapta meg. Az Öltettốl a filmig sorozat elsố darabja errốl a filmrôl még „,azon melegében”, szintén 1967ben jelent meg. Az állandó sorozatszerkesztô Dr. Ujhelyi Szilárd mellett Nádasy László neve van föltüntetve a kötet szerkesztôjeként.

Regény és film szorosabb összehasonlítására ebben a tanulmányban nem vállalkozom, ahogy az Ötlettốl a filmig kötet sem teszi, noha ez talán elvárható volna egy ilyen jellegú munkától. Ennek részben az lehet a magyarázata, hogy Kovács filmje meglehetôsen hú adaptációnak számít. Mind Cseres könyve, mind Kovács filmje klasszikusan modernista eszközökkel él. ${ }^{[2]}$ Valós történelmi eseményt mutat be mindkét mû́: 1942-ben a Bácskában állomásozó magyar katonai alakulatok a megerôsödött szerb partizánakciókra reagáltak a razziával. Feketehalmy-Czeydner Ferenc és Grassy József több városban, faluban is kijárási tilalmat, a civil lakosság ellenôrzését, az Újvidéken áthaladó vonatokon utazók igazoltatását rendelte el. Január 20. és 23. között a razzia katonai túlkapásba torkollott, s a csendôrség részvételével együtt 3300-3800, fôleg szerb és zsidó civil, valamint magyar kommunista párttag kivégzését eredményezte. A könyv és a film egyaránt négy fiktív, bíróság elé állított katona szemszögéból mutatja be ezen három nap eseményeit. Modernizmus alatt tehát elsôsorban a többszempontú, szubjektív, alineáris narratívát kell értenünk, amivel regény és film új fénytörésbe helyezi a kanonizált, hivatalos történeti narratívát. Amennyiben 1964-67 között beszélhetünk egyáltalán hivatalos narratíváról, a hatalom által képviselt emlékezeti politikáról az újvidéki események kapcsán, hiszen, ahogy látni fogjuk, alig jelent meg a történtekrôl a Hideg napokon kívül más munka a korszakban. Ha van két narratíva (történeti és fikciós), akkor szembenállásuknak fontos eleme, hogy Feketehalmy-Czeydnert és Grassyt is kivégezték háborús búneik miatt mint az eseményekért felelôs vezetôket; a regény és a film azonban a katonai vezetôk felelôsségén túl a katonaság kollektív, illetve az egyes katonák egyéni felelôsségének kérdést firtatja, hiszen az ítélethirdetés elôtt játszódik a történet.

A Hideg napokat bemutató Ötlettól a filmig kötet négy fejezetre tagolódik: Dokumentumok, A forgatókönyv 
, A közönség, Az alkotók. Az elsô fejezet történeti szövegek válogatása, a második az irodalmi forgatókönyvet tartalmazza a filmből vett illusztratív képekkel, a harmadik egy ankét eredményeit mutatja be, a negyedik pedig egy-egy esszét tartalmaz Cseres és Kovács tollából. Annak ellenére, hogy ez volt az elsô Ötlettôl a filmig kötet, a könyvben sehol sem találunk orientáló, bevezetố vagy értelmezô szöveget, ami az olvasónak segítene tájékozódni abban a tekintetben, hogy mi volna a könyv célja pontosan. Még a fülszöveg sem definiálja a könyv szándékait, itt is csupán egy olyan idézetet találunk Cseres regényéből, amely a filmben is elhangzik.

\section{Dokumentumok}

Ez a fejezet kronológiai sorrendben tár az olvasó elé mintegy harminc oldalnyi írásos dokumentumot a razziáról. Itt gazdag értelmet nyer az Ötlettól a filmig cím, különösen Cseres ezen mondata felől közelítve: „[...] körültekintésem az ügyben a szükségesnél is nagyobb volt, és húsz évnél is hosszabb ideig tartó."[3] Mintha valóban azt igyekezné ez a fejezet rekonstruálni az olvasó számára, milyen élmény lehetett az írónak levéltárakban anyagot gyújteni a regényhez, amikor még gyakorlatilag nem született az újvidéki eseményekrôl történelmi munka. ${ }^{[4]}$ A szerkesztôi kommentárok minimálisak, nem értelmeznek és kontextualizálnak, leginkább csak a dokumentumok forrását, keletkezésének idejét, esetleg szerzőjét közlik, s a könyv végén pontos forrásjegyzéket is találunk.

Az első közölt dokumentum 1942. január 4-i keltezésû: részleteket olvashatunk a Belügyminisztérium közbiztonsági osztályának telefonügyeletes naplójából. Ezek a szövegek a magyar sereg ellen elkövetett elsô partizánakcióról számolnak be, amelyre a katonaság hivatalos narratívája szerint a razzia csupán ellenreakció volt. Noha a regény és a film cselekménye szempontjából (amely az 1942. január 20-23-i eseményekre szorítkozik) igen korai idôponttól kezdi a könyv elénk tárni az újvidéki eseményeket, az utolsó dokumentum nem FeketehalmyCzeydner és Grassy kivégzéséröl, hanem a szökésükrôl szól. Mintha „cliffhanger” dramaturgiát alkalmaznának a szerkesztôk, hogy izgalmat keltve az olvasóban átlendítsék a következô fejezethez. Itt aztán valóban a forgatókönyv elsô oldalán értesülni fogunk róla, hogy a razzia két felelôsét 1946-ban kivégezték.

Természetesen nincs az a háttérbe húzódó szerkesztôi magatartás, amely ne hozna létre egyfajta narratívát. Jelen esetben azt tapasztaljuk, hogy a dokumentumválogatás sokszor brutálisabb részleteket tár elénk, mint Cseres regénye vagy Kovács filmje. Több dokumentum alapján is úgy tûnik, hogy a bácskai razzia idôben és térben is jóval kiterjedtebb volt, mint azt a Hideg napokban olvassuk és látjuk. „Egy budapesti detektív”[5] már január 17-én arról számol be, hogy Zsablyán, Csurgon, Titelen, Sajkásgyörgyén és Boldogasszonyfalván is tisztogatás folyt. Jelentése tanúsága szerint már ekkor is a környék befagyott folyóinak jege alá süllyesztették a holttesteket, ami a filmben igen fontos motívummá válik majd, és körülbelül ezer lakos eltûnésérôl ad számot. Megjelenik továbbá az a tény, hogy a razzia során gyerekeket, csecsemóket is gyilkoltak, amit késôbb Dr. Babós József tanúvallomása is megerôsít: „Ezen a napon körülbelül 53 csecsemôt öltek 
meg."[6] A gyerekgyilkosságokról sem a filmben, sem a regényben nem esik szó. Egy másik detektív jelentésében ezt olvashatjuk: „Tisztelettel jelentem, hogy a katonaság újvidéki akciójával kapcsolatosan olyan hírek vannak forgalomban, hogy egyes katonák az agyonlôtt személyek gyưrûs ujjait és füleit levágták, hogy az ékszereket gyorsabban eltulajdoníthassák."[7]

Szintén az események brutális mivoltát támasztják alá azok a dokumentumok, amelyek ezen jelentések ellenére a razzia eltussolásáról beszélnek. Ezek között van Dr. Ferbach Péter újvidéki főispán ,javaslata” is, melyben a fôispán azt nehezményezi, hogy az újvidéki kivégzésekrôl szóló tudósításokat némely újság „túlságosan kiszínezte”, s azzal a határozott kéréssel fordul a sajtóhoz, hogy „amennyiben ilyen szabotázs- vagy terrorcselekmény előfordul, vagy csak pár sorban emlékezzenek meg róla, vagy teljesen hallgassák el; ha pedig ilyen cselekményekbôl kifolyólag bírósági ítéletek hozatnak, azoknak száraz közlésére szorítkozzanak csupán."[8] A magyar honvédvezérkar szintén azzal a kéréssel fordult a Külügyminisztériumhoz, hogy a kivégzésekrôl készült „fényképfelvételeket felkutassák, és az elôtalált felvételeket, azok negatívjaival együtt (diapozitívokat is), haladéktalanul elkobozzák, tekintet nélkül arra, hogy azok polgári vagy katonai személyeknél találtatnak."[9]

A másik fontos különbség a Hideg napok és a dokumentumgyưjtemény narratívája között, hogy utóbbi folyamatosan jelzi a razziával, és annak módszereivel szembeni fellépést magyar katonai oldalról. A fent idézett detektívek beszámolóiból is azt látjuk, hogy január közepén már elegendô információ állt a Belügyminisztérium rendelkezésére ahhoz, hogy megtegye a razzia leállításához szükséges lépéseket. Emellett a kötet hosszan idézi Bajcsy-Zsilinszky Endre Horthy Miklóshoz intézett emlékiratát, amelyben páratlan szókimondással és bátorsággal vonja felelôsségre Bárdossy miniszterelnököt és Horthyt: „én még január 21-én délután 2 és 3 óra között figyelmeztettem a miniszterelnök urat a zsablyai vérfürdôre [...] Megállapítottam a miniszterelnök úr súlyos politikai felelôsségét ebben a kérdésben: nem mondhatja, hogy senki sem figyelmeztette volt idejében."[10] Bajcsy-Zsiliniszky szövegéhez hasonló funkciót tölt be a dokumentumválogatásban a Kommunisták Magyarországi Pártjának 1942. február 6-án kiadott röpirata, amely határozott politikai és morális kritikát gyakorol: „Délvidéken több ezer polgári lakost ítélet nélkül végeztek ki Horthy hóhérlegényei. Gépfegyverrel lekaszabolták két délvidéki falu ártatlan lakosságát. Újvidék tiltakozását vérbe fojtották, és számtalan békés polgárát legyilkolták."[11] Ám ennek a tiltakozásnak és kiállásnak gyakorlati haszna kevés volt: a felelősöket a hadbíróság ítélte el elôször 1943-ban, majd 1946-ban újra, még a kommunista hatalomátvétel elôtt. Ha szemügyre vesszük, hogy BajcsyZsilinszky és a Kommunisták Magyarországi Pártjának szövegén kívül a harminc oldalnyi dokumentum túlnyomó többsége a razziát végrehajtó magyar katonaság különböző intézményeitôl származik, akkor világossá válik a válogatás üzenete: a történtek ellen csak a szociáldemokrata Bajcsy-Zsilinszky és a kommunisták emeltek szót. A kötet további részeit vizsgálva látni fogjuk, hogy nagyon is indokolt volt ez a „hazabeszéd”, hiszen Cserest és Kovácsot egyaránt vádolták „nemzetgyalázással” a Hideg napok kapcsán, a közönségnek nehezére esett elfogadni, hogy a látottakat magyar katonák német befolyás nélkül elkövethették. Kétségtelen tény az is, hogy sem a regény, sem a film nem mutat föl szignifikáns ellenállást egyetlen szereplô 
részérôl sem az eseményekkel szemben, legfeljebb az ellenállás lehetôségét demonstrálja (pl. Kászoni karakterén keresztül).

A fejezethez kapcsolódó jegyzetek között az eredeti források mellett három történelmi munkára is hivatkoznak a szerkesztôk: Búzási János: Az újvidéki „razzia” (Kossuth Könyvkiadó, 1963), Karsai Elek: A budai Vártól a Gyepúig 1941-1945 (Táncsics Könyvkiadó, 1965), Ádám Magda, Juhász Gyula, Kerekes Lajos: Magyarország és a második világháború (Kossuth Könyvkiadó, 1959). Azonban ezekből a munkákból sem idézi a kötet a szerzók mondatait, innen is kizárólag eredeti forrásszövegeket emeltek át.

Összességében elmondhatjuk, hogy a Dokumentumok fejezet hiteles, ellenôrizhetôen hivatkozott dokumentumokat tartalmaz. Ez a fejezet a Hideg napok történelmi hátterének forrásvidékét tárja elénk: azt mutatja be, milyen szövegek olvasása ihlethette a szerzóket.

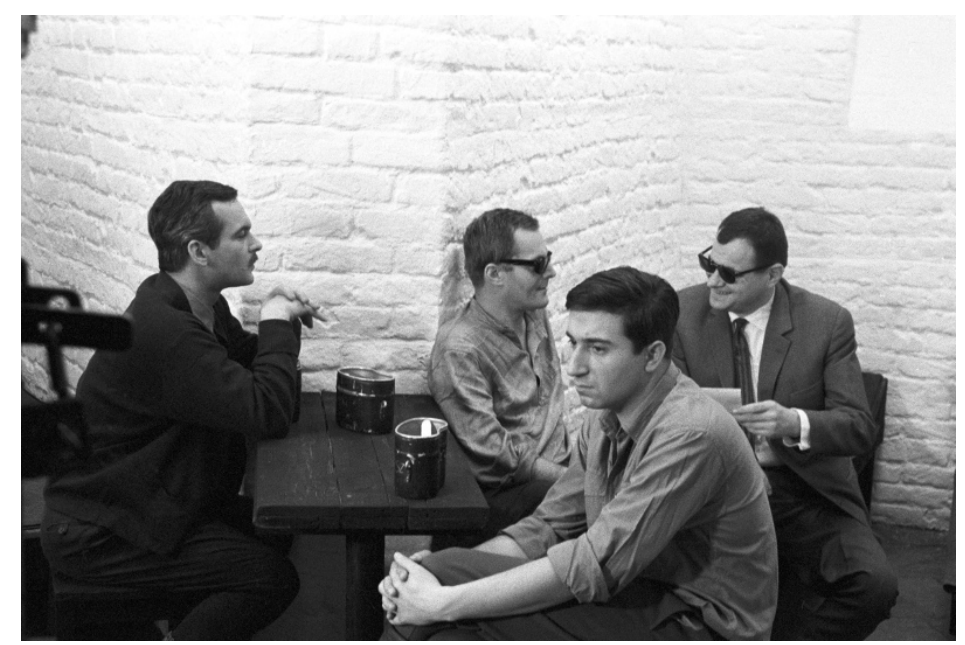

A Hideg napok forgatásán. Balról jobbra: Latinovits Zoltán, Darvas Iván, Szilágyi Tibor, Kovács András. Forrás: http://mandarchiv.hu

\section{A forgatókönyv}

A könyvben a forgatókönyvet tartalmazó fejezet az elsô pont, ahol utalást találunk arra a tényre, hogy a film regényadaptáció, bár itt sem teljesen világos ez az információ: „A STUDIÓ 1. BEMUTATJA / HIDEG NAPOK / címú filmjét / Írta Cseres Tibor / Forgatókönyv Kovács András”. ${ }^{12]}$ A kötet egészen Cseres esszéjéig nem említi egyértelmúen, hogy adaptációról van szó, s azért is furcsa Cserest a forgatókönyv címlapján föltüntetni, mert késôbb az író maga hívja föl a figyelmet arra, hogy „igazából, elejétól végéig egyetlen forgatókönyvet sem írtam”, ${ }^{[13]}$ s hosszan taglalja, mennyire kívülállónak tartja magát a filmszakmában.

A kötetben közölt forgatókönyv lényeges filológiai kérdéseket vet föl. A publikált forgatókönyv szövege nem egyezik a Magyar Nemzeti Filmarchívumban ôrzött forgatókönyvével. ${ }^{[14]}$ Ennek több oka is lehet, s idejekorán érdemes leszögeznünk, hogy ebben a konkrét esetben a korszakban „megszokottól” eltérốen nem cenzurális változtatásokról van szó. Sokkal inkább a forgatókönyvek 
publikálásával kapcsolatos általános problémák és kérdések merülnek föl a két szöveg összevetésekor.

Ezt az összetett kérdéskört a következóképp foglalhatjuk össze Steven Price The Screenplay ${ }^{[15]}$ címú könyve alapján. A forgatókönyv-szövegek státusza a mai napig nem konszenzuális a filmtudományi diskurzusban. Ennek elsôdleges oka az, hogy a forgatókönyvet ipari (industrial), funkcionális, alkalmazott szövegnek is tekinthetjük, amely a film létrejöttével tulajdonképpen létjogosultságát veszti. Másodszor nem hagyhatjuk figyelmen kívül azt a tényt, hogy a legtöbb film esetében nem egy, hanem számos forgatókönyv-verzió (drafts) születik, amelyek közül egyet szokás véglegesnek tekinteni - magyarul ezt általában technikai forgatókönyvnek hívják (angolul: final shooting draft), amely annyiban különbözik az úgynevezett irodalmi forgatókönyvtől, hogy a tervezett plánméretekkel föltördelik a szöveget. Ennek ellenére gyakran előfordul forgatás közben, hogy az alkotók visszatérnek egy korábbi verzió megoldásaihoz, a színészek némiképp megváltoztatják a dialógus szövegét, stb. Ilyen értelemben tehát a filmmel létrejön egy újabb, hipotetikus forgatókönyv-változat, amely azonban papíron nem létezik. Amikor egy forgatókönyv publikálására kerül sor, a kiadónak mérlegelnie kell, hogy milyen céllal közli a szöveget, s ennek megfelelôen kell a fenti problémákkal szembenéznie. A mai napig az a jellemzó eljárás, hogy a végsố technikai forgatókönyvet közlés elôtt átírják, megszerkesztik, a filmhez igazítják a szöveget, s a technikai jellegú utasítások zömét törlik. Ez a szokás egyrészt a laikus érdeklődoók számára is hozzáférhetôvé, „könnyen fogyaszthatóvá”, jobban olvashatóvá teszi a forgatókönyveket, másrészt az otthoni videózás és a digitalizáció korszaka elôtt az ilyen szövegek nagy segítséget jelentettek a kutatók számára a filmek elemzésekor (Price ezt a funkciót a mnemonikus szóval jelöli). Az ilyen jellegú véglegesítés a mai kutatói sztenderdek szerint már önkényesnek számít, s helyette a kritikai kiadás gyakorlatát szokás elốnyben részesíteni, ám a könyvkereskedelem piaci helyzete miatt forgatókönyvek esetében ez még ritkábban fordul elô, mint irodalmi múveknél.

A Hideg napok forgatókönyvénél is azt látjuk, hogy a Filmarchívumbéli technikai forgatókönyvhöz képest az Ötlettốl a filmig kötetben az elkészült film alapján átszerkesztett szöveget publikáltak. Ennek leglátványosabb jele tipográfiai: a hatvanas években Magyarországon még az volt a forgatókönyvírói gyakorlat, hogy egy oldalon két oszlopban futott a szöveg: bal oldalt a képek, helyszínleírások, mozgások, jobb oldalt a hanghatások, dialógusok, monológok; aláhúzást igen, kurzívot egyáltalán nem használtak. A kötetben ehhez képest egy folyamatosan futó szöveget olvashatunk, amely a színpadi drámák tipográfiai konvencióit követi: a helyszínleírások kiemelés nélkül szerepelnek, a megszólalók neve csupa kapitális, utána kettôspont majd a hangzó szöveg, a cselekvések pedig kurzívval szedve. Ez a Hideg napok esetében azért is érdekes, mert a filmben sok az olyan szekvencia, amelyben narratív monológot (voice-overt) hallunk, miközben a képen flashbackként jelenik meg az elbeszélés. Az ilyen megoldások ábrázolása a forgatókönyvben mindig problémát jelent, hiszen a szöveg nem képes szimultán audiovizuális hatások érzékeltetésére. Részben ennek a problémának a feloldására alakult ki anno a két oszlopos forgatókönyv formája (ami mára kikopott a szakmából), amihez képest a folyamatosan futó szöveg visszalépésnek is tûnhet, hiszen így a narratív monológot mindig meg kell törni, hogy a változó képi információt is 
közölni lehessen. A Filmarchívumban örzött forgatókönyvben számozva szerepelnek a tervezett beállítások méretei, amit a kötetbeli szövegből alapvetôen elhagytak, bár néhány dramaturgiailag indokolt helyen meghagyták a „közelkép” és egyéb kifejezéseket.

Ezen változtatások alapján úgy túnik, az Ötlettôl a filmig kötet célközönsége a politikailag nyitott és a filmmúvészet iránt érdeklődő olvasó lehetett (a Hideg napok kötetét 4000 példányban nyomtatták ki), mivel a közölt forgatókönyv-szöveg teljesen alkalmas a fönt említett mnemonikus funkció betöltésére is. Ahogy a sorozatról szóló egyik elsô recenzióban Ember Marianne fogalmaz: „A filmmúvészet iránt érdeklődô olvasók régi igényét elégíti ki a Magvetô könyvkiadó, amikor az „Ötlettól a filmig« sorozat megindításával - az olasz Cappelli-kiadó példája nyomán - kötetenként egy-egy film megszületésének fôbb állomásait kívánja bemutatni."[16] Ember Marianne recenziója 1968-ban, tehát egy évvel a kötet megjelenése után látott napvilágot, az ô írásánál korábban pedig csak kiadói értesítések jelentek meg a sorozatról. A késôi reakció ellenére már Ember Marianne is kritikus hangnemben ír arról, hogy a magyar könyvkiadás milyen késôn kezdett foglalkozni a filmes szakmai „múhelytitkokkal”. Nem tekinthetjük teljesen igazságosnak a kifogást, mert az egész sorozat 13 éves pályafutása korrelál a korszakra jellemző európai forgatókönyv-publikálás gyakorlatával.

Ami az általános publikációs kérdéseknél érdekesebb, hogy a tipográfiai igazításoktól eltekintve a két szöveg közti eltérések száma minimális. Természetesen vannak olyan képek a filmben, s következésképp olyan szövegek a kötetben, amelyek nem szerepelnek a technikai forgatókönyvben, de fundamentális különbségek (pl. jelenetek sorrendjének változása, megszólalások sorrendjének változása, dialógusok és narrációk szövegének változása, helyszínleírások különbsége, stb.) alig tapasztalhatók. Kovács technikai forgatókönyve 80-90\%-ban egyezik azzal, amit a filmben látunk. Ez igen ritka és magas aránynak számít a forgatókönyvek nagy többségéhez képest, s arra vall, amit késôbb a rendező esszéjében is tapasztalunk majd, hogy Kovács rendkívül tudatosan elôretervező alkotó volt. Érdemes azt is megemlítenünk, hogy a forgatókönyv és film narratív struktúrájának egyezése nagyban köszönhetô Cseres könyvének is, hiszen ezen a téren nincs lényegi különbség regény és film között: a filmben hallható, illetve mindkét forgatókönyvben olvasható narratív voice-overek mind szó szerint követik a regény eredeti szövegét.

Fontos eltérés a technikai forgatókönyv és a kötetben publikált között a nyitókép. A technikai forgatókönyvben a börtönudvar leírását olvashatjuk, amely így végződik: „A fekete ajtó betölti a képet, megáll a gép, felirat jelenik meg”. ${ }^{[17]}$ Ezt követôen egy nagyon hasonló bevezetô szöveget közöl a technikai forgatókönyv, mint amit a filmben maga Kovács András olvas föl. Ehhez képest a kötetben publikált forgatókönyv és a film is így kezdôdik: „A fớcím után a befagyott Dunát látjuk. A jégen robbanás, lék keletkezik, ennek kimerevedett képe látható a következô szöveg alatt",,18] majd ismét a bevezetố szöveget olvashatjuk. Ebból a különbségből a film egyes részleteinek keletkezéstörténetére következtethetünk. 


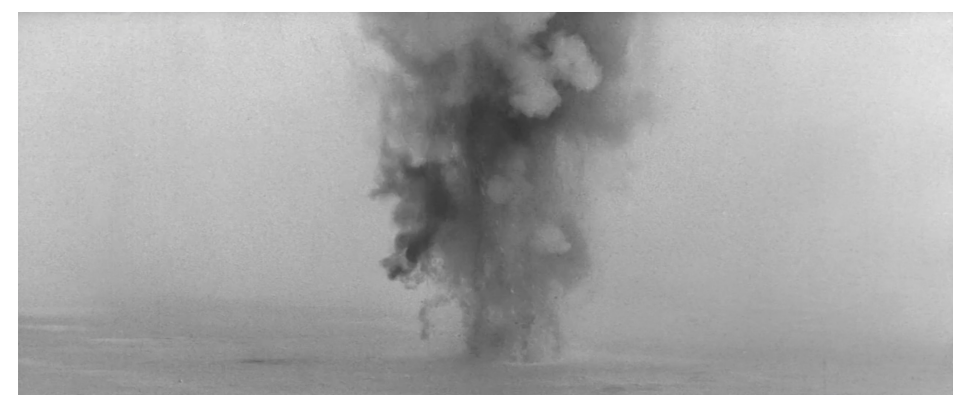

Lékrobbantás. Kovács András: Hideg napok

A Hideg napok filmváltozatának rendkívül fontos eleme, hogy két motívummal is utal a holokausztra: egyik ezek közül a civilek Dunába lövése, amelynek képi feldolgozása szorosan kötôdik Máriássy Félix Budapesti tavasz (1955) címú filmjéhez. Máriássy a zsidók folyóba lövését a hiánnyal ábrázolja: csak a rakparton felsorakozó embereket, majd az utánuk a rakparton maradt ruhákat és cipóket látjuk, kivégzésüket nem. Kovács ehhez hasonlóan számtalan képen mutatja be, ahogyan a civileket a befagyott Dunán robbantott léknél fölsorakoztatják, mutatja az utánuk maradt ruhák eltakarítását is, de konkrét erôszakot nem ábrázol - csakis a civileket kivégzô Dorner tizedes (Avar István) lelövését mutatja meg a razzia végeztével. Így válik a tömegirtást reprezentáló képpé a befagyott Dunán robbantott lék. A másik jelenet, mely a soát idézi, az újvidéki vonatállomáson játszódik, ahol Tarpataki (Darvas Iván) egy pénztárosnô (Horváth Teri) segítségét kéri az utazók igazoltatásához. A civilek leszállnak a vonatról, a pénztárosnőnek pedig meg kell mondania, kit ismer arcról, és kit nem, majd egy csendôr ennek alapján jobbra és balra küldi az embereket - amiként az Auschwitzba vonattal deportált emberekrôl egy orvos szava alapján döntötték el, hogy a gázkamrába vagy a barakkokba mennek. Ennek a jelenetnek a leírása néhány szónyi eltéréstôl eltekintve megegyezik a technikai és a kötetben publikált forgatókönyvben. A két szöveg kezdete alapján mégis arra következtethetünk, hogy a befagyott Dunán látható lék motívummá alakítása, amivel nézetem szerint Kovács az újvidéki razziát a magyar holokauszt eseményei közé emelte, csak a forgatás vagy a vágás során merülhetett föl a rendezôben.

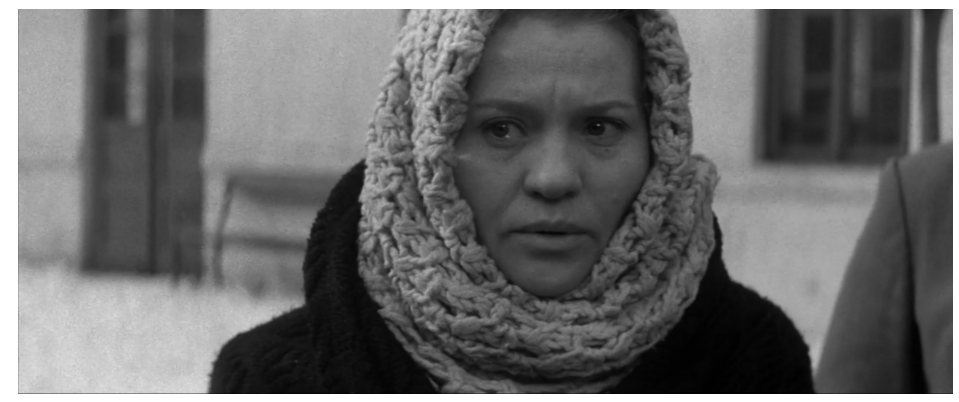

A pénztárosnö (Horváth Teri). Kovács András: Hideg napok

Az ehhez hasonló szignifikáns eltérések a két szöveg között azonban ritkák. Kovács láttató erejú, a film vizuális világát megalapozó mondatait általában szó szerinti egyezéssel találjuk meg mindkét szövegben: „Börtöncella. Csak a rácsok, az ajtó és a bakancsok feketék, különben minden világos. (Ez a tónus jellemző az egész filmre, mintha régi, napszítta fényképet látnánk, ahol az árnyalatok már elmosódtak.)"[19] Máshol költői eszközök használatát is tapasztaljuk: „Pozdor a medence 
szélén megy végig - a gép kíséri -, mintha emberfejek tengere fölött lépkedne." ${ }^{[20]}$ Ahol nem tapasztalható szó szerinti egyezés, ott is azt látjuk, hogy Kovács aprólékosan, elôre megtervezte a képi szekvenciákat. Bükyné Rózsa (Bara Margit) bemutatása így áll a technikai forgatókönyvben:

Bükyné Zoltánkát kezdi fürdetni, Büky közben a vizet szabályozza, ügyetlen. Edit segíti. Bükyné tartózkodóan köszöni meg. [...] Bükyné befejezte Zoltánka fürdetését, lefekteti. Edit újra szolgálatkészen már gondoskodott az ágynemürôl. [...] Bükyné a fürdôszobából figyel kifelé, mit beszélhetnek Bükyék, de azok csak a gyerekkel foglalkoznak. ${ }^{[21]}$

A kötetben ugyanezt a szekvenciát így olvashatjuk:

Bükyné Zoltánkát fürdeti; a háttérben Edit és Büky, aki épp a vízcsappal babrál. [...] Edit a hálószobában szolgálatkészen ágyaz. Bükyné Zoltánkát hozza a fürdôszobából, mögötte Büky jön. [...] Bükyné belép a fürdôszobába; megáll az ajtónál, hallgatózik. [22]

Nézetem szerint a technikai forgatókönyvhöz képesti (bár nem számottevô) változtatások a kötetben kontraproduktívak. Nemcsak kutatói szempontból irreleváns egy „visszaírt” forgatókönyv tanulmányozása, de a laikus olvasó számára sem különösebben érdekes, hiszen ha valaki a filmkészítés folyamatára kíváncsi, és a szerkesztôk ezt az igényt igyekeznek kielégíteni, akkor éppen azt volna érdemes a kötetnek fölmutatnia, hogy az elôkészítés fázisában a forgatókönyv még számos ponton eltér a majdani kész filmtól. Az ilyen szignifikáns eltérésekre, mint a film nyitóképe, nyugodtan utalhatnának a szerkesztôk lábjegyzetekben. A filmmel teljes azonosságban álló, „visszaírt” forgatókönyvszöveg a mnemonikus funkciót ugyan teljesíti, azonban vajmi keveset mond arról, hogyan jutottak el az alkotók az ötlettól a filmig.

\section{A közönség}

A kötet ezen részét teljes egészében Taródi-Nagy Béla $A z$ elsố ezrek véleményéból címú tanulmánya teszi ki. A tanulmány hat ankét (ezt ma tesztvetítésnek hívhatnánk) eredményét közli. A szöveg elsố része az általános tudnivalókat foglalja össze az ankétok körülményeiról, az összes további pedig egy-egy társadalmi csoport véleményét oly módon, hogy Taródi-Nagy elôször pár bekezdésben leírja a tanulságokat, majd részleteket közöl az ankéton begyújtött kérdôívekre adott válaszokból.

Noha a kérdôíveket a Filmarchívum Ké 149/8-as ${ }^{[23]}$ dossziéjának tanúsága szerint a résztvevôk anonim töltötték ki, van némi furcsaság abban, hogy a válaszok egy részét a könyvben publikálták. A fent említett dosszié ugyanis Taródi-Nagy tanulmányának elsô változatát tartalmazza, melynek borítóján ez áll: „Zárt anyag. Csak igazgatói engedéllyel adható ki. / 1966. IX. 20.”[24] A Filmtudományi Intézet igazgatója a kötet közlésekor Ujhelyi Szilárd volt, aki, mint korábban már utaltam rá, a teljes Ötlettốl a filmig sorozat szerkesztôje is egyben. A publikáláshoz szükséges igazgatói engedély tehát minden bizonnyal megvolt, ám a dossziéban található mintakérdôíven ez 
a mondat is szerepel: „A vizsgálat, amelyhez ezúton az Ön közremúködését is kérjük, kizárólag tudományos kutatás céljait szolgálja." ${ }^{[25]}$ Az anonimitás ellenére ennek fényében fölvethetố a kérdés, hogy mennyiben volt etikus az ankétok résztvevôinek válaszait a szélesebb nyilvánosság elé tárni.

A tanulmány szövegét a publikáláshoz a forgatókönyvéhez hasonlóan átszerkesztették. Az esetek többségében ez rövidítést jelent: leginkább azokat a szakaszokat húzták ki, amelyek egyértelmúen jelzik, hogy a felmérés belsô használatra készült. Így például a Ké 149/8-as dosszié szövegéból kiderül, hogy az ankétok idốpontja megelôzte a magyarországi bemutatót:

A film nemzetközi elismerést szerzett, mielôtt a magyar közönség elé került volna. Különösen fontos tehát, hogy közönségünk is megfelelố fogadtatásban részesítse. A vizsgálat célja a kijelölt közönségrétegeken keresztül bepillantást nyerni a film várható közönség-, politikai- és társadalmi visszhangjába, mindenekelôtt azért, hogy a film forgalmazását, propagandáját ezek ismeretében készítsék elő.[26]

A fenti szakaszt így fogalmazták át a közléshez: „A Filmtudományi intézet a Hideg napok címú, Karlovy Varyban fôdijjat nyert film közönséghatását a Filmföigazgatóság által kijelölt helyeken, idốpontokban és csoportokon megvizsgálta." ${ }^{[27]} \mathrm{Az}$ ankétok dátumait Taródi-Nagy a tanulmány egyik szövegváltozatában sem közli, annál részletesebben ír arról, hogy melyik ankét milyen napszakban történt, hányan vettek részt a vetítésen, milyen kedélyállapot uralkodott a teremben, $\mathrm{s}$ hogy milyenek voltak a vetítési körülmények. A fölmerült technikai nehézségek kapcsán a szerző konkrét javaslatokat is megfogalmaz a Filmfôiigazgatóság számára a Ké 149/8-as dosszié tanulmányában:

A Filmfőigazgatóságnak intézkednie kellene, hogy a cinemascope vetítési helyeken a vetítési felület, a vetítési távolság, a fényerô és áramerôsség megkívánt minimális szintjeit biztosítsák. A Hideg napok-at csak ilyen helyeken lehet levetíteni, mert a filmben szereplô állandó fehér háttér ellenfényes hatásban a nagy gonddal kidolgozott színészi arcjáték különben megsemmisül. ${ }^{[28]}$

Ennek kapcsán fontos leszögezni, hogy Taródi-Nagy a Ké 149/8-as tanulmány szövegében sehol sem említi a film cenzúrázásának kérdését. A kutatás nem azt vizsgálta, be szabad-e mutatni a filmet, hanem azt, hogy a bemutatás milyen vitákat generálhat. A kötetben közölt változat olvasása során viszont fölmerülhet a gyanú, hogy az ankétokat cenzurális okból szervezték, mivel a húzások olyan mértékúek és jellegúek, hogy nem derül ki pontosan a kutatás célja, ellenben a közönségtôl idézett vélemények gyakran a bemutatás ellen érvelnek. A Ké 149/8-as szöveg álláspontja ellentétes ezzel: „(...) nem a Hideg napok címú film vizsgázott a közönség elôtt, hanem éppen megfordítva, a közönség vizsgázott." ${ }^{[29]}$ Taródi a filmet voltaképpen remekmúnek tartja, s a kitöltött kérdőívek nyomán fölmerüló értelmezési nehézségeket minden esetben klasszikus baloldali társadalomelméleti paradigmák mentén értelmezi: 
Szeretnénk ugyanis jelentésünk, e véleménygyưjteményünk olvasóit objektív tárgyi bizonyítékokkal meggyôzni, hogy a film hatását a film míves oldalú tényezői mellett mennyire befolyásolják a személyiség, a nézô, a közönség, végsőfokon a társadalom oldaláról ható tényezôk. ${ }^{[30]}$

A mintakérdőív és az idézett válaszok alapján a kutatás két kérdésre koncentrált: egyrészt a Hideg napok Magyarországon újszerünek számító alineáris, több nézôpontú elbeszélooi szerkezetének érthetôségére; másrészt hogy miként reagál a közönség a magyar katonaság háborús búneire, melyet a film a korszak diskurzusával ellentétben nem a nemzeti szocialista Németország befolyásával magyaráz. Taródi-Nagy a kérdôíveket egy némiképp leegyszerúsített osztályelmélet alapján értékeli, s ezek alapján fogalmazza meg a film terjesztésére vonatkozó javaslatait. Az ankétokról a legobjektívebb képet a következô összefoglaló táblázat ${ }^{[31]}$ nyújtja:

\begin{tabular}{|c|c|}
\hline A csoport megjelölése & A vetítésen megjelentek kb. száma \\
\hline $\begin{array}{l}\text { TIT értelmiségi klub - Salgótarján, } \\
\text { ahol hosszabb idô óta filmklub } \\
\text { múködik }\end{array}$ & 200 \\
\hline Pedagógusok, pontosabban a & \\
\hline $\begin{array}{l}\text { Pedagógus Szakszervezet } \\
\text { funkcionáriusai, közöttük a járási és } \\
\text { budapesti kerületi titkárok }\end{array}$ & 350 \\
\hline 15-18 éves gimnazista lányok a & \\
\hline $\begin{array}{l}\text { nagykőrösi önkéntes ifjúsági } \\
\text { táborban }\end{array}$ & 150 \\
\hline $\begin{array}{l}\text { A honvédség, a hadsereg Budapesti } \\
\text { Tisztiház szervezésében }\end{array}$ & 500 \\
\hline $\begin{array}{l}\text { Munkások az újpesti Duna } \\
\text { Cipógyárból }\end{array}$ & 200 \\
\hline $\begin{array}{l}\text { Termelöszövetkezeti parasztok - } \\
\text { Törtel község, Pest megye }\end{array}$ & 260 \\
\hline & 1660 \\
\hline
\end{tabular}

Taródi-Nagy véleménye szerint „legjelentôsebbnek az ország lakosságának 61\%-át reprezentáló törteli vizsgálati csoport helyzetét kell mondanunk", ${ }^{[32]}$ amely vélekedését azzal indokolja, hogy „[a]z ország lakosságának 61\%-a falvakban él”. [33] A szerzô rangsorolása szerint ezután a Cipőgyári dolgozók, majd az ifjúsági tábori lányok véleménye a legfontosabb, mivel: „[t]ársadalmunkban a nôk arányszáma magasabb, mint a férfiaké, a mozik nézôterén viszont a nézőknek csak mintegy harmada nô."[34] A kötetben közölt szövegbool kihúzták azt a szakaszt, melyben Taródi-Nagy kifejti, hogy a felmérésben vizsgált csoportok arányai nem felelnek meg a valós társadalmi arányoknak, s így a szerzố elismeri, hogy a kutatás nem tekinthetố reprezentatívnak. Ehelyett ez a mondat került 
a kötetbe:

Amikor a film és a társadalom érintkezési felületét vizsgálva a vizsgálati tömegben viszonylag kisebb arányban jelen lévő és fejletlenebb közönségréteg jelentőségét hangsúlyoztuk, akkor az adott film, tehát a Hideg napok várható társadalmi érvényesülésének irányára és realitására akartunk utalni. ${ }^{[35]}$

Mikor a késôbb idézett válaszok szövegi minőségét jellemzi, így ír:

Az egyes vizsgálati csoportok válaszait olvasva meggyőződhetünk arról, hogy a csiszoltság és a primitívség nem azonos az adekváltság és inadekváltság kategóriáival. Sok csiszolt fogalmazás üres, az ellenôrzô kérdések bizonyítják, hogy téves vagy hamis. Ugyanakkor nem egy primitív fogalmazás, pl. az újpesti munkások esetében - adekvát kifejezését adja a film bennük létrejött konkrét hatásának. ${ }^{[36]}$

Taródi-Nagy munkás-paraszt társadalomként írja le a magyar lakosságot, s igyekszik empátiával viszonyulni az alsóbb társadalmi osztályokhoz. Olyannyira, hogy ahol lehetôsége van rá, ott statisztikai adatok alapján vagy stilisztikai csúsztatásokkal felülértékeli a törteli parasztok és a cipógyári dolgozók válaszait. Ez abból is látszik, hogy mind a dossziéban, mind a kötetben közölt tanulmányban Taródi-Nagy többet idéz ettôl a két csoporttól, mint a maradék négytôl.

Mindezek ellenére a kötetben közölt tanulmány további részében akadnak izgalmas és érdekes válaszidézetek. Például a magyar filmek lassúságával és unalmasságával kapcsolatos elôítéletek már ekkor a közbeszéd részét képezték: „»Elég unalmas. Hány éves a rendező felesége? Egyszóval unalmas volt, mint a többi magyar film." / (17 éves, ált. iskolát végzett férfi)”; ${ }^{[37] ~ " » N e m ~ t e t s z e t t ~ a ~}$ vontatottság, ez sajnos, magyar filmhiba. Összekuszált volt. Sok helyen figyelni kellett a cselekményre. A mozi nem matematika óra." / (19 éves, középiskolát végzett nô)".[38]

Annak ellenére, hogy még Gelencsér Gábor is hangsúlyozza a film hiánypótló közéleti tematikáját,[ ${ }^{39]}$ sokan úgy érezték, hogy a Hideg napok más háborús filmekhez képest redundáns: „»Nagyon sok háborús film van világszerte, miért kell ezzel foglalkozni annyit?« / férfi, kor és isk. végzettség megjelölése nélkül)”; ${ }^{[40] ~ „ » N e m ~ v o l n a ~ t e h e t s e ́ g e ~ v i ́ g ~ f i l m ~ a l k o t a ́ s a ́ r a ~ i n k a ́ b b ? ~ E z ~ m a ́ r ~ m e g s z o k o t t ~ a ~}$ szovjet filmek errôl szólnak." / (Föiskolát végzett férfi, korát nem jelölte meg)”. ${ }^{[41]}$ A háborús témával szembeni unalom különösen érdekes annak fényében, hogy a Ké 149/8-as dossziéban sok válaszoló 1946-ra tette a film cselekményének idejét, bár ezeket a kötetból kihagyták. ${ }^{[42]}$ Szintén ide kapcsolható, hogy többen is a Szegénylegényekhez (Jancsó Miklós, 1966) hasonlították a filmet: „»Rendkívül megrázó volt számomra, hasonló benyomást kelt a Szegénylegényekéhez.« / (16 éves)”; [43] „NNem érzi gondolatilag ismétlésnek ezt a filmet a Szegénylegények után.« / (27 éves, egyetemet végzett férfi)". [44] 
Taródi-Nagy a tanulmány vége felé közeledve így reflektál a fenti idézetek közt tapasztalható véleménykülönbségekre:

(...) mintha más filmet látott volna a törteli paraszt, mint az újpesti munkás, a pedagógus értelmiségi és még inkább a filmmúvészeti készültséggel is rendelkezô salgótarjáni TIT értelmiségi klub tagja. Nem. A film ugyanaz volt. A különbség a nézőben volt. Ez a különbség nem áthidalhatatlan. ${ }^{[45]}$

Az idézetból kiolvasható edukatív szándék nemes célnak tetszik, bár a könyvben közölt szövegból nem derül ki világosan, mire utal Taródi. A Ké 149/8-as dosszié jóval árnyaltabb képet nyújt a felmérésrốl, mint a kötet szövege. A dossziéban található tanulmányból kiolvasható az ôszinte társadalomjobbító szándék, mintha Taródi-Nagy valóban arra vágyna, hogy a Hideg napok minél szélesebb nézôközönséghez jusson el, s az osztálykülönbségek ne akadályozzák a film befogadását. A kötet szövege a húzások miatt spekulatív kutatásnak hat, melynek célja pusztán az volt, hogy a megrendelôk elôzetes hipotéziseit igazolja. Pedig a fentiek fényében egyértelmúnek tûnik, hogy a tanulmányt éppen a könyv edukatív aspektusának erôsítése miatt válogatták be a szövegek közé.

\section{Az alkotók}

A kötetet záró fejezetében olvasható esszék némiképp párbeszédben állnak a fent idézett nézôi véleményekkel. Mind Cseres, mind Kovács alapvetôen a befogadók reakcióira építve számol be mûve keletkezésérôl, az alkotással való szándékairól.

Cseres Tibor esszéje az elsô olyan pont a kötetben, ahol világossá válik, hogy a film regényadaptáció és nem dokumentumigényú alkotás. Cseres rögtön a szöveg elején levelekre hivatkozik, amelyeket a regény megjelenése után kapott. Ezek alapján három megközelítési módot javasol saját könyve olvasásához: egyszerre tartja történelmi, búnügyi és lelkiismereti regénynek a Hideg napokat. Utóbbit úgy emlegeti mint a nemzet lelkiismereti múvét: világosan kijelenti, hogy a regény alapjául szolgáló újvidéki razzia számára éppen azért fontos, mert a német megszállás elootti korszak eseménye, s mint ilyen, nem kényszerítő erő hatására történt, hanem tisztán a magyar fasizmus eredménye. Ezen gondolatát igazolandó idézetet is közöl a hozzá írott levelekből, melyekből az derül ki, hogy az újvidéki események nem egyedülállóak:

Bezdában például 3-án minden embernek a futballpályára kellett mennie, kidobolták, hogy akit otthon találnak, fóbe lövik. A futballpálya két oldalán géppuskák voltak felállítva. Az összegyúlt tömegböl kiválasztották a húsz és ötven közötti férfiakat, és százhuszonegyet még aznap kivégeztek, gramofonszó mellett [...] ${ }^{[46]}$

Ahogy korábban már utaltam rá, Cseres beszámol saját szerepérôl is a film létrejötte kapcsán. Kutatásom szempontjából itt a legfontosabb, ahogyan az író az adaptáció természetére és 
konkrétan a Hideg napok adaptálásra reflektál: „Szándékosan nem azt mondom, hogy különbség keletkezik [regény és film között - Sz.B.], mert az egész cselekmény s valamennyi mondat, amely a vászonról elhangzik szó szerint a regényból kerülhetett elô, $\mathrm{s}$ a szándék is egyezhet papíron és vásznon, a távolság mégis meglesz." [47] Cseres is meglehetôsen hú és pontos adaptációnak tartja a filmet. Máshol leírja, hogy elégedett a minőségével, s örül neki, hogy a film szélesebb, nemzetközi közönség elé tárja a múben taglalt kérdéseket. Mi több, azzal is tisztában van, hogy a film mint médium talán nagyobb hatásfokkal képes a nézôket ezekkel a kérdésekkel szembesíteni: „A film hatása nemcsak azért dinamikusabb, mert a látványra feledkezô nézôt robogás által kapja el, hanem azért is, mert a rendezô parancsára, az operatốr mozgékony figyelme elôtt 10-20 kitúnô színész gyốz meg arról, amit az író egymaga igyekezett szuggerálni könyve átnyújtásakor."[48] Cseres ezen mondatai végre kárpótolnak bennünket azért, hogy a kötetben eddig egyáltalán nem esett szó a film irodalmi forrásáról. Enélkül a könyv címének elsố szava, az ötlettôl nem teljesülne maradéktalanul. Emellett Cseres utal Kovács adaptációjának azon vívmányára, hogy a film nem át, hanem bedolgozza a regény szövegét a film szövetébe: a cellában elhangzó monológok nem pusztán narratív alapanyagként funkcionálnak a filmhez, hanem - Deleuze fogalmával élve hangképpée[49] válnak.

Az esszé legizgalmasabb része az, ahol Cseres ugyan csak áttételesen, de lényegében felelôsségre vonja a közbeszédet alakító vagy ellenôrzô személyeket. Nehéz ennél pontosabban fogalmazni, mert Cseres sem írja le konkrétan, hogy mit hiányol a közbeszédbôl. Elismeri, hogy a regényrôl és a filmról is születtek kritikák, tud a fönt tárgyalt ankétokról, mégis úgy érzi a hozzá érkezett magánlevelek alapján, hogy ennél többen szeretnének fölszólalni az ügy kapcsán. A szöveg ezen részéból arra lehet következtetni, hogy Cseres a kifejezés „ortodox” értelmében kommunista szerzônek tartja magát, akit a mú létezésénél jobban érdekel a mú által elérhetô társadalmi változás, a mú által provokált közéleti vita, a mú politikai hatása. Cseres ezzel rendkívül elégedetlen, s félreérthetetlenül másokat tart mindezért felelôsnek:

Említettem már, sok levél által kapott és szóbeli megnyilatkozások sokasága bizonyítja számomra, hogy érdemes lett volna helyet adni lapjainkban az olvasók és filmnézók ellentmondásos vélekedésének. Hogy ez nem történt meg, azzal csak hátráltattuk irodalmi és olvasó közgondolkodásunk fejlődését. ${ }^{[50]}$

Az esszé végén Cseres még ennél is konkrétabban kijelenti, hogy érzése szerint ô elvégezte az általa vállalt feladatot, ám nem szeretné, ha az újvidéki razziához hasonlatos közügyek múvészetipolitikai kibeszélése ezzel befejeződne. „A Hideg napok egy lehetséges ciklus kezdete, első darabja. Szeretném, ha nem nekem kellene folytatnom."[51]

Kovács András Cseresénél jóval hosszabb esszéje költôien szólva éppen ezt teszi: folytatja a ciklust. Nemcsak úgy kapcsolódik Cseres gondolataihoz, hogy beszámol róla, mennyire nem hagyta nyugodni a regény megfilmesítésének gondolata az elolvasása után, hanem ennél jóval szerteágazóbban írja le véleményét a hatvanas években Magyarországon uralkodó állapotokról. Az Egy film drámája az általam ismert ekkoriban született szövegek közül az egyik legradikálisabb 
rendszerkritikát nyújtja, ami lehetôséget nyújt számunkra, hogy a Hideg napokat is szélesebb kontextusban értelmezzük a film cselekményének történelmi távlatánál.

Az esszé tanúsága szerint már a könyv megfilmesítését sem volt egyszerú tetô alá hozni. Kovács leírja, hogy a regény megjelenése és filmje forgatása között többen is fölvetették az adaptáció lehetôségét, ám vagy elutasításba ütköztek, vagy bátortalanságba torkollott a kezdeményezés. Állítása szerint a forgatás közben is sokan ellenezték a film létrejöttét, mert „»egy hortysta tiszt melodrámájának « tartották a Hideg napok-at”. [52] Ezen körülmények elemzése kapcsán Kovács pontosan megfogalmazza az öncenzúra jelenségét a korszak alkotói gyakorlatában: „a múvészekben gyakran olyan gátlások is hatnak, amelyeket túlzott óvatosság diktál”, ${ }^{[58]} \mathrm{s}$ úgy véli, hogy mindez szoros összefüggésben áll a közelmúlt eseményeinek kibeszéletlenségével, feldolgozatlanságával:

Hogy csak egyes címszavakat említsek: az első világháború és az azt követő forradalmak, a trianoni békeszerződés, Horthyék irredentizmusa és a bécsi döntésekkel megváltozott határok, II. világháborús szereplésünk, a zsidók deportálása, a felszabadulás, a személyi kultusz korszaka, az 1956-os ellenforradalom. ${ }^{[54]}$

Ezen események egyetlen mondatban való közös említése 1967-ben szokatlanul nyílt és bátor fogalmazásnak tetszik.

Az öncenzúra jelensége párhuzamba állítható a Hideg napok cselekményének kibontakozásával is: a filmben is azt látjuk, hogy az ellenállás lehetôsége idôrôl idôre fölmerül, fôleg Tarpataki, illetve Büky részérôl, ám a hadseregben uralkodó hierarchikus tömegpszichózis nem enged utat ennek. Kovács mindezt a „véleménynyilvánítás demokratikus formáinak” hiányaként detektálja, s egy ponton a totalitárius rendszerek logikájával teljesen szemben állva azt írja: „a teljes egyetértést tartjuk normának - holott ez a rendkívüli -, és a nézeteltéréseket kellemetlennek, pedig ez a természetes állapot."[55]

Voltaképpen Kovács esszéje és Hideg napok címú filmje egyaránt értelmezhetô a patriarchális, hierarchikus és autoriter rendszerek bírálataként. Amint arra fönt utaltam, a filmben léptennyomon ott van a razzia megakadályozásnak lehetôsége, de egyfolytában azt látjuk, hogy a demokratikus joggyakorlattal szemben mindig az erôszak gyốz. Amikor a ranglétrán feljebb álló személyek kifogynak a józan érvekból, vagy mikroagresszióval, vagy tettleges fizikai erôszakkal állítják félre az ôket megkérdójelezóket. Amikor az egyik legény (Madaras József) nem akarja folytatni az éjszakai ôrjáratot a hidegben, Dorner tizedes felpofozza. Amikor Tarpataki nem hajlandó megérteni a vonatállomáson, hogy igazoltatás vagy bekísértetés helyett Grassy (Major Tamás) mire utal a „más mód”, illetve „intézd el ôket” kifejezésekkel, akkor Grassy üvölt és leváltja Tarpatakit. Amikor Grassy irodájában Büky (Latinovits Zoltán) fölvállalja a konfliktust felettesével szemben, Grassy atyáskodva ironizál Bükyvel, hogy nyugodtan jelentse föl, tagadja meg parancsait, hiszen erre a szolgálati szabályzat lehetôséget ad. Büky narrációjában még reflektál is a jelenségre: „Ez a gúny teljesen megbénított. Arra képtelen voltam gondolni, milyen jogaim 
vannak, csak Grassy arcát láttam, ahogy fölényesen kigúnyol."[56] Kovács az ehhez hasonló jelenetekhez a következốt fúzi hozzá esszéjében:

Amikor arra hivatkoztam, hogy még a Horthy hadsereg szolgálati szabályzatában is benne van, hogy a katona »köteles megtagadni a parancsot, ha az nyilvánvalóan törvényellenes«, a fiatalok, akik pedig hamarosan bevonulnak, egyszerúen nem hitték el, mint ahogy azt sem hitték el sokan, hogy a mi hadseregünk szabályzatában is benne van ez a jog. ${ }^{[57]}$

Kovács a kérdés kapcsán több olyan hatvanas évekbeli társadalmi jelenségról ír esszéjében, amelyek szintén a fent említett autoriter rendszer részének tekinthetôk. Ilyen például az általa „ikonmániának” nevezett fenomén, amivel a személyi kultusz és a tekintélyelvúség maradványait bírálva felemlegeti Lenin képretusálási gyakorlatát vagy Mao túlértékelését Marx szellemi teljesítményéhez képest: „Marx sem járt jobban, ötven évvel a forradalom után, s lassan 90 évvel a halála után még mindig nem jelent meg múveinek kritikai kiadása az összes fennmaradt szöveggel. Lehet, hogy teljes Maónk hamarabb lesz?"[58] Látnivaló, hogy Kovácsot mindezek a kérdések a fiatalabb generáció sorsa, áttételesen tehát az ország jövője miatt érdeklik. Kritizálja az érettségi és egyetemi felvételi pontrendszert, illetve a KISZ szerepét ebben a folyamatban, amely szerinte a tanulókat formalizmusra és teljesítménykényszerre, nem pedig kreatív önmegvalósításra, emancipatórikus magatartásra neveli. Marx eredeti értékkritikája szerint a Kovács által a ,jegyek fetisizálásának” nevezett jelenség könnyen párhuzamba állítható a pénz munkásra gyakorolt uniformizáló hatásával: annyit érsz, amennyit a munkád, illetve a dolgozatra kapott jegyed. Nem nehéz belátni Kovács igazát a film kontextusában: egy ilyen autoriter iskolarendszerben nevelkedett generációból kihal az ellenállásra, a kritikára, az ellentmondásra, a forradalomra való hajlam - a Hideg napok téthelyzetében valószínúleg nem tagadnák meg a gyilkolás parancsát. Nemcsak a mai magyar közoktatási rendszer juthat eszünkbe, ha Kovács fölvetéseinek aktualitásán gondolkodunk, hanem akár a kötet megjelenése után egy évvel Párizsban bekövetkezett '68-as események is: egyetlen karhatalmi szerv sem tagadta meg a tiltakozókkal szembeni erôszak alkalmazását, hogy ne a korábbi '56-os tömegbe lövetésre utaljunk éppen.

A film patriarchátussal kapcsolatos, keveset tárgyalt vonása Büky Rózsa alakja, s a rajta keresztül megjelenített narratíva. A magam részérôl odáig mennék, hogy implicit feminista filmnek tekintsem a Hideg napokat. Ahogyan Taródi-Nagy tanulmányában az egyik nézó fogalmaz: „»Ez a világ a férfiak világa, a rendezô világában a háború is csak a férfiak ügye. A nốk csak illusztratív szerepet töltenek be. Rózsa sorsa viszont azt mutatja, hogy mindez nem így van, mert sok tragédiát mutat, de az igazi tragédia Rózsáé, a nôé« / (35 éves, egyetemet végzett nô)". ${ }^{[59]}$ Valóban azt látjuk, hogy a férfiak fönt már tárgyalt hibái miatt három nevesített nốt loonek bele a Dunába: Büky feleségét; Editet (Vass Éva), a zsidó szolgálónôt; és Milénát (Szemes Mari), a másik szolgálónôt. Ne feledjük el azt sem, hogy a film elején a tárgyalásra várakozó három fogságban lévő katona között is Tarpataki feleségének levelei miatt indul be igazán az újvidéki napokra való visszaemlékezés. Büky tulajdonképpen kiprovokálja Tarpatakiból, hogy vallja be: ô is megcsalta abban a három 
napban a feleségét, amivel Büky csak saját bûntudatát igyekszik enyhíteni. Innen nézve a film teljes cselekményét olvashatjuk úgy, mint egy „ártatlannak” induló afférból kibomló tragédiát. A filmben ábrázolt elsố erőszakos halál is nôhöz kötôdik: a pénztárosnốt Tarpataki tévedése miatt lövik le. Az éjszakai ôrjárat során a Dorner-raj nemcsak megöl két zsidó lányt, Szabó tizedes (Szirtes Ádám) arról is beszámol, hogy megerốszakoltak egy nôt: ugyan csak homályos utalásokat tesz az aktusra, amiként Kovács is a hiánnyal ábrázolja az abúzust (akár a lékkel a tömeggyilkosságot); Dorner odakínálja a pálinkát az ágyban fekvố nônek, majd visszavágunk a cellába, ahol Szabó a nô mellének állagát írja le. Ez a rendezői megoldás morális állásfoglalásnak is tekinthetô: tudósít a nốt ért erôszakról, de az ábrázolás eszközeivel, a kihagyással megôrzi a nő testének és lényének méltóságát.

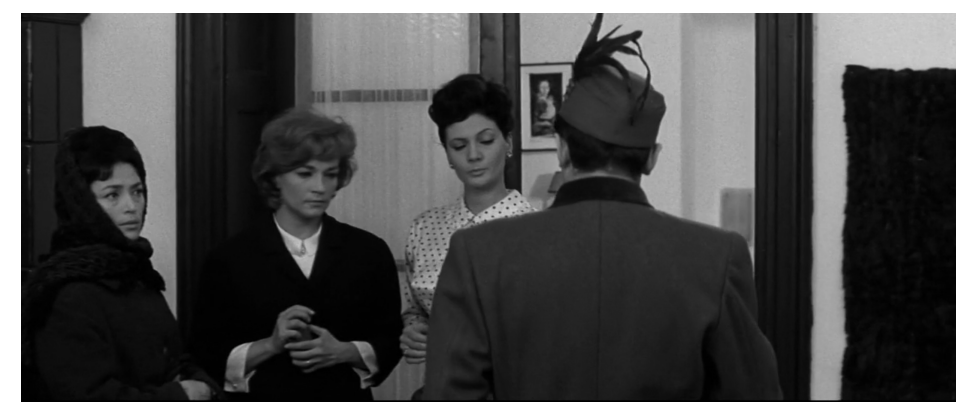

Balról jobbra: Milena (Szemes Mari), Edit (Vass Éva), Bükyné Rózsa (Bara Margit), Képiró fóhadnagy (Öze Lajos). Kovács András: Hideg napok.

Büky, Rózsa, Edit és Miléna esetében a legerôsebb ez a fókusz. Büky saját hútlenségét azzal a szolgálati rendelettel indokolja, amelyben megtiltották, hogy a tisztek családjukat Újvidékre vigyék. Abban a pár napban, amíg a rendelet érvényben volt, Büky megkörnyékezte Editet, miután saját és felesége antiszemitizmusán „átküzdte” magát. Jegyezzük meg, milyen pontosan rögzítik itt Cseres mondatai a korszak szalon antiszemitizmusának fogalmi- és gondolatrendszerét: „,...házigazdáimról tudtam, hogy rendezetlen származásúak...”, ,...érezd úgy, mintha magyarok között laknál...”, „feleségem antiszemitizmusából egyre kevesebb józan érvet találtam...” Büky mikroagressziója: „Az asszony, ha támadtam, egy mozdulattal sem segített, de nem is állt ellent" - egy ilyen aktust semmiképp sem tekinthetünk konszenzuálisnak, Büky egyértelmúen az erôszak keretrendszerén belül cselekszik már itt is. Rózsa megérkezése után Büky számára sokáig nagyobb problémát jelent ezen affér eltitkolása, mint szolgálati kötelességeinek teljesítése. A kijárási tilalom bevezetése után Rózsa lesz az elsô, aki el akar menni Újvidékrôl, de Büky leinti. Amikor a férfi belátja felesége igazát, már késô, és hiába próbálja családját kimenteni a városból, a nôk a léknél végzik. Bükyné Rózsa hôstette abban nyilvánul meg, hogy antiszemitizmusát nemcsak egy affér, egy tárgyiasított nô képének kedvéért számolja föl, mint férje, hanem valóban meglátja Edit és Miléna lényében az emberi értéket: „Nagyon megszerettem”, mondja, mi több „barátnőimként” hivatkozik a két nôre, amikor arra kéri férjét, hadd vigye ôket is magával Pestre. Kovács esszéjében azt írja Bükyné Rózsáról, hogy „sokkal férfiasabban viselkedett, mint a tisztikar nagy része".[60] 
Mindent egybevetve elmondhatjuk, hogy Kovács esszéje megvilágító erejú. Már-már nehéz megérteni, hogyan jelenhetett meg a kötetben ez a szöveg 1967-ben. Valószínúleg nem véletlen, hogy az Ötlettôl a filmig könyvekrôl született kritikák egyikében sem írnak az esszé rendszerkritikai elemeirôl, hanem inkább a filmrôl szóló kritikák és Kovács „forgatási naplójának” közlését hiányolják. ${ }^{[61]}$ Pedig Kovács gondolatai igen sokat segítenek abban, hogy a Hideg napokat a történelmi keretnél jóval tágabb kontextusban értelmezzük.

\section{Összefoglalás}

A Hideg napokat bemutató kötetnek jól detektálható dramaturgiája, szerkezete van: a történelmi dokumentumoktól jutunk el a forgatókönyvig, majd az ankétok eredményeitôl, a nézők reakcióitól az alkotók gondolataiig. A kötet tartalma alapján arra lehet következtetni, hogy a könyv edukatív szándékkal jött létre, mivel számos, a kötetben található szöveg hangsúlyozza, hogy a film közéleti tematikája és modernista elbeszélô technikája miatt sok nézô számára nehezebben befogadható volt. A kötet több része is olyan háttérinformációkra kíván rávilágítani, amelyek a film értelmezését segíthetik. Ilyen szempontból egyértelmúen kanonizáló szándékkal lép föl a könyv: egy szélesebb közönséggel szeretné elfogadtatni a Hideg napok múvészi értékeit. Ennek ellenére sem a kötetet, sem a filmet közvetlenül magyarázó, értelmező szöveggel nem találkozunk, ám a könyv egészének világos az üzenete: ez a múalkotás, ezek a kommunista múvészek feldolgozták a Horthy-korszak búneit.

Forráskritikailag a kötet megbízhatósága nem egységes: a történeti dokumentumok ellenôrizhetôk, a forgatókönyv szövege és a Taródi-Nagy-tanulmány csak utólagosan, a Filmarchívum dokumentumai nyomán, az alkotói esszék kapcsán ilyen probléma nem merül föl. Az elsố kötet sajtóvisszhangja igen minimális, de alapvetôen kedvezố volt.

A forgatókönyvírás-kutatás szempontjából a könyv arról tanúskodik, hogy a korszakban egy forgatókönyv publikálását, valószínúleg a múfaj szokatlansága miatt, erôsen kontextualizálni kellett. Ezt erôsíti a filmbôl visszaírt, utólagosan szerkesztett szöveg jellege. Cseres regénye és az abból született forgatókönyv textuális különbségeire és hasonlóságaira leginkább Cseres esszéje reflektál a könyvben. Mint korábban utaltam rá, ezzel együtt a kötetben közölt forgatókönyvszöveg is fölmutat sajátosan filmírói minôségeket: jellemzôen éppen olyan szakaszokon, ahol a filmben hangzó narráció szó szerint Cseres regényéból származik, a képi információk pedig Kovács vizuális narrációjának leirataként jelennek meg a papíron.

1. Kovács András: Egy film drámája. In Ötlettôl a filmig - Cseres Tibor, Kovács András: Hideg napok. Szerk. Dr. Ujhelyi Szilárd, Nádasy László. Budapest, Magvető, 1967. 172.

2. Errôl bővebben lásd: Gelencsér Gábor: Forgatott könyvek - A magyar film és az irodalom kapcsolata 1945 és 1995 között. Budapest, Kijárat Kiadó - Kosztolányi Dezsô Kávéház Kulturális Alapítvány, 2015. 247252. 

napok Szerk. Dr. Ujhelyi Szilárd, Nádasy László. Budapest, Magvető, 1967. 170.

4. Tudtommal az elsô ilyen könyv: Búzási János: Az újvidéki „razzia”. Budapest, Kossuth Könyvkiadó, 1963.

5. Ötlettôl a filmig - Cseres Tibor, Kovács András: Hideg napok. Szerk. Dr. Ujhelyi Szilárd, Nádasy László. Budapest, Magvetô, 1967. 8.

6. Ötlettól a filmig - Hideg napok. 13. A kötetben jelölt forrás: NOT Feketehalmy-Czeydner Ferenc és társai elleni per. 15-18.

7. $\quad$ Ötlettól a filmig - Hideg napok. 22. A kötetben jelölt forrás: PI Archívum. Bm. VII. res. 1942. — 1 6279.

8. $\quad$ Ötlettôl a filmig - Hideg napok. 20. A kötetben jelölt forrás: OL Küm. Sajtóoszátly. 1941. — 3 - 39. res.

9. $\quad$ Ötlettôl a filmig - Hideg napok. 20. - a kötetben jelölt forrás: OL Küm. Sajtóosztály. 1941. — 3 $676 /$ res.

10. Ötlettôl a filmig - Hideg napok. 17. - a kötetben jelölt forrás: Istorijski Arhiv P. K. SK. Novi Sad (Jugoszlávia) 3634.

11. Ötlettôl a filmig - Hideg napok. 19. - a kötetben jelölt forrás: Istorijski Arhiv P. K. SK. Novi Sad (Jugoszlávia) 3634.

12. Ötlettól a filmig - Hideg napok. 33. (kapitális, kiemelés az eredetiben - Sz. B.)

13. Cseres Tibor: i.m. 161.

14. Kovács András: Hideg napok. Technikai forgatókönyv, MFTIA Könyvtára, 1965. 1286.

15. Price, Steven: The Screenplay. Authorship, Theory and Criticism. / Editing and Publication. Basingstoke New York, Palgrave - Macmillan, 2010. 94-111.

16. Ember Marianne: Magyar filmek alkotói múhelyében. Filmkultúra, 1968. február 1.

17. Kovács Anrás: Hideg napok. Technikai forgatókönyv, MFTIA Könyvtára, 1965. 1286, 1.

18. Ötlettól a filmig - Hideg napok. 34 .

19. A mondat a technikai forgatókönyvben: Kovács András: i.m. 1286, 2.; a kötetben pedig: Ötlettôl a filmig - Hideg napok. 35.

20. A mondat a technikai forgatókönyvben: Kovács András: i.m. 1286, 83.; a kötetben pedig: Ötlettôl a filmig - Hideg napok. 91.

21. Kovács: i.m. 1286, 38-39.

22. Ötlettôl a filmig - Hideg napok. 52-53.

23. MFTIA Könyvtára 1158.

24. Taródy Béla: Hideg napok Elözetes hatásvizsgálat. MFTIA Könyvtára, 1966, 1158. (A borítón TaródiNagy neve valóban Y-al és második vezetéknév nélkül szerepel, az elsô oldalon már ebben a dokumentumban is Taródi-Nagy.)

25. Taródi-Nagy: i.m. 1158.

26. Taródi-Nagy: i.m. 1158. 1.

27. Taródi-Nagy Béla: Az elsố ezrek véleményébốl / I. In Ötlettôl a filmig - Hideg napok. 117.

28. Taródi-Nagy: i.m. 1158. 13.

29. Taródi-Nagy: i.m. MFTIA Könyvtára, 1158, 4.

30. Taródi-Nagy: i.m. MFTIA Könyvtára, 1158, 4.

31. Taródi-Nagy: i.m. 117. 
33. Taródi-Nagy: i.m. 117.

34. Taródi-Nagy: i.m. 118.

35. Taródi-Nagy: i.m. 118.

36. Taródi-Nagy: i.m. 119.

37. Taródi-Nagy: i.m. 124. (kiemelés az eredetiben - Sz.B.)

38. Taródi-Nagy: i.m. 150. (kiemelés az eredetiben - Sz.B.)

39. „[...] e múvek nem pusztán a hiányzó közbeszéd szerepét veszik magukra egy-egy, a nyilvánosság elôtt még ki nem beszélt téma exponálásával, hanem múvészi eszközeikben is eredetit alkotnak."

Gelencsér Gábor: i.m. 250.

40. Taródi-Nagy: i.m. 121. (kiemelés az eredetiben - Sz.B.)

41. Taródi-Nagy: i.m. 141. (kiemelés az eredetiben - Sz.B.)

42. „Az évszám nem elírás, nagyon sok válaszban így szerepelt.” Taródi-Nagy: i.m. MFTIA Könyvtára $1158,19$.

43. Taródi-Nagy: i.m. 134. (kiemelés az eredetiben - Sz.B.)

44. Taródi-Nagy: i.m. 149. (kiemelés az eredetiben - Sz.B.)

45. Taródi-Nagy: i.m. 140.

46. Gseres Tibor idéz egy hozzá írott levélból. Cseres Tibor: Hideg napok: regény és film. In Ötlettôl a filmig - Hideg napok. 169-170.

47. Ciseres: i.m. 160.

48. Ciseres: i.m. 160.

49. Deluze, Gilles: Az idô-kép, Film 2. / A kép alkotórészei / 3. Ford. Kovács András Bálint. Budapest, Palatinus, 2008. 291-314.

50. Cseres: i.m. 167

51. Cseres: i.m. 171.

52. Kovács András: Egy film drámája. 173.

53. Kovács: i.m. 173.

54. Kovács: i.m. 191.

55. Kovács: i.m. 174.

56. A filmból vett idézetek forrását nem jelölöm külön.

57. Kovács: i.m. 215.

58. Kovács: i.m. 198.

59. Taródi-Nagy: i.m. 142. (kiemelés az eredetiben - Sz.B.)

60. Kovács: i.m. 201.

61. Lásd: Vasárnapi Könyvespolc / Ötlettől a filmig: Hideg napok (Szerzô: z.l.). Magyar Nemzet, 1967. január 31.; Földes Ilona: Ötlet és film. Magyarország, 1968/49.

\section{Irodalomjegyzék}

- Ádám Magda, Juhász Gyula, Kerekes Lajos: Magyarország és a második világháború. Kossuth Könyvkiadó, 1959. 
- Búzási János: Az újvidéki „razzia”. Budapest, Kossuth Könyvkiadó, 1963.

- Cseres Tibor: Hideg napok: regény és film. In Ötlettôl a filmig. Cseres Tibor, Kovács András: Hideg napok. Szerk. Dr. Ujhelyi Szilárd, Nádasy László. Budapest, Magvetô, 1967. 157-171.

- Ember Marianne: Magyar filmek alkotói múhelyében. Filmkultúra, 1968. február 1.

- Földes Ilona: Ötlet és film. Magyarország, 1968/49.

- Gelencsér Gábor: Forgatott könyvek - A magyar film és az irodalom kapcsolata 1945 és 1995 között. Budapest, Kijárat Kiadó - Kosztolányi Dezsố Kávéház Kulturális Alapítvány, 2015.

- Karsai Elek: A budai Vártól a Gyepúig 1941-1945. Táncsics Könyvkiadó, 1965.

- Kovács András: Egy film drámája. In Ötlettôl a filmig. Cseres Tibor, Kovács András: Hideg napok. Szerk. Dr. Ujhelyi Szilárd, Nádasy László. Budapest, Magvetô, 1967. 172-219.

- Ötlettốl a filmig -- Cseres Tibor, Kovács András: Hideg napok. Szerk. Dr. Ujhelyi Szilárd, Nádasy László. Budapest, Magvetô, 1967.

- Price, Steven: The Screenplay. Authorship, Theory and Criticism. Basingstoke and New York, Palgrave Macmillan, 2010.

- Taródi-Nagy Béla: Az elsô ezrek véleményéből. In Ötlettôl a filmig. Cseres Tibor, Kovács András: Hideg napok. Szerk. Dr. Ujhelyi Szilárd, Nádasy László. Budapest, Magvetô, 1967. 115155.

• z.l.: Vasárnapi Könyvespolc / Ötlettôl a filmig: Hideg napok. Magyar Nemzet, 1967. január 31.

Archívumi források:

- Kovács András: Hideg napok. Technikai forgatókönyv, MFTIA Könyvtára, 1965. 1286.

- Taródy Béla: Hideg napok. Elôzetes hatásvizsgálat. MFTIA Könyvtára, 1966. 1158. Ké 149/8.

\section{Filmográfia}

- Budapesti tavasz (Máriássy Félix, 1955)

- Hideg napok (Kovács András, 1966)

- Szegénylegények (Jancsó Miklós, 1966) 
(C) Apertúra, 2020. tél | www.apertura.hu

webcím: https://www.apertura.hu/2020/tel/szollosi-a-hideg-napok-genezise-\%e2\%88\%92-otlettol-

a-filmig/

https://doi.org/10.31176/apertura.2019.15.2.6

(Q)opertúro 